\title{
The efficiency and safety of recombinant factor VIla for bleeding in patients without haemophilia: a meta-analysis of 12 randomized controlled trials
}

\section{Ying Zhang}

Zhejiang University School of Medicine Sir Run Run Shaw Hospital

\section{Yuting Wang}

Zhejiang University School of Medicine Sir Run Run Shaw Hospital

\section{Youfa Zhou}

Zhejiang University School of Medicine Sir Run Run Shaw Hospital

Jian Li

Wenzhou Medical University

Haiyan Zhou ( $\nabla 2185031 @ z j u . e d u . c n ~)$

Zhejiang University School of Medicine Sir Run Run Shaw Hospital

Research article

Keywords: bleeding, recombinant factor VIla, thromboembolic events

Posted Date: December 16th, 2019

DOI: https://doi.org/10.21203/rs.2.18751/v1

License: (c) (i) This work is licensed under a Creative Commons Attribution 4.0 International License. Read Full License 


\section{Abstract}

Background: Recombinant factor VIla (rFVlla) is widely used for off-label indications to control bleeding and reduce blood transfusion. However, the efficacy and safety of rFVIla for bleeding in patients without haemophilia are uncertain and worthy of further study. This meta-analysis has been updated to incorporate recent trial data.

Methods: We searched the Cochrane Central Register of Controlled Trials (CENTRAL), PUBMED, EMBASE and other medical databases up to 20 July 2019. The results of this work are synthetized and reported in accordance with the PRISMA statement.

Results: Twelve trials met our inclusion criteria. High dose rFVlla reduced the requirements of red cell transfusion (mean difference [MD], -232.34; 95\% confidence interval [Cl]; -448.33 to 234.89). rFVIla did not significantly affect mortality (relative risk[RR], $1.00 ; 95 \% \mathrm{Cl}, 0.82-1.21$ ), total thromboembolic events (RR, $1.13 ; 95 \% \mathrm{Cl}, 0.94-1.36)$, myocardial infarction ( $R R, 1.37 ; 95 \% \mathrm{Cl}, 0.92-2.05)$, deep vein thrombosis (RR, $0.83 ; 95 \% \mathrm{Cl}, 0.52-1.33)$, ICU-stay (RR, $0.40 ; 95 \% \mathrm{Cl},-1.28$ to 2.07 ) and numbers of patients for red cell transfusion (RR, 0.94; $95 \% \mathrm{Cl}, 0.83-1.08)$. However, it may increase the incidence of arterial events (RR, $1.38 ; 95 \% \mathrm{Cl}, 1.08-1.77)$.

Conclusion: High dose rFVIla is effective to reduce the need of red cell transfusion for bleeding in patients without haemophilia. However, it may increase the risk of arterial events.

\section{Background}

Massive bleeding and the need for blood transfusion are common complications of major surgery, both of which are associated with postoperative mortality and poor long-term prognosis [1,2]. Minimizing the use of limited resources, such as blood products, is essential and the application of hemostatic drugs is of great concern.

Recombinant human factor VIla ( $\mathrm{rFVlla}$ ) is a new type of drug with pro-coagulant effect [3]. Its pharmacological function is to induce local activation of platelets to produce thrombin, and to help form stable fibrin clots at the site of vascular injury [4]. Use of rFVIla has been approved for the treatment of bleeding in patients with hemophilia A and B, acquired hemophilia, factor VII deficiency, or Glanzmann thrombasthenia refractory to platelet administration [5]. Since 1999, when rFVlla was successfully used in animal experiments to control life-threatening hemorrhages, attention has been focused on the use of rFVIla in patients at risk of refractory or severe bleeding [6]. At present, more and more studies have applied rFVIla in the prevention and treatment of severe trauma, liver transplantation, Cardiac surgery, spontaneous intracerebral hemorrhage and other diseases prone to massive bleeding and surgical operations [7].

However, there is no clear benefit or risk analysis of the use of rFVlla. First, existing research for single use dose range $(11-180 \mathrm{mcg} / \mathrm{kg})$ [8], the traditional drug delivery after the determination of plasma can only 
prove the existence of the rFVlla and dosing success, not about its hemostatic effect [9], which makes the best dose the only feasible method is to observe the ending events, such as blood loss, transfusion needs, the incidence of adverse events, etc. Therefore, we compared the effect of dose on effectiveness, so as to increase the incidence of adverse events such as thromboembolism instead of poor clinical effect due to unreasonable use. Secondly, due to the pharmacological effect of rFVIla on inducing thrombin production by activating platelets and promoting fibrin clot formation, it also increases the potential risk of extra-target thromboembolic events. Most indications in study of the current randomized controlled trials of clinical application of the results were negative [7], in view of the analysis of literature quality security problems, not the end of the detailed division of various adverse events, such as arterial embolism, myocardial infarction, venous thrombosis, deep vein thrombosis, etc., so we focus on assessment of the safety problems.

Because rFVIla is widely used in various refractory hemorrhagic diseases, its safety and efficacy are still uncertain [10], and more quality and statistically significant data are needed to guide off-label application, new experimental results are needed to update guidelines to adjust clinical practice. Studies considering other systems focused on selected groups of participants or were conducted before many randomized controlled trials (RCT) publications. This review will critically evaluate the results of different identification trials and extend the early Cochrane findings for systematic review by including as many additional trials as possible.

\section{Methods}

\section{Literature Search and Selection}

Four trained investigators independently searched for comprehensive systematic literatures in PubMed, Cochrane library, Embase and Web of Science from January 2008 to July 2019. The search strategy included the following terms: factor VIla, recombinant activated factor VII, recombinant factor VIla, NovoSeven, rFVlla, Factor 7A, Factor Seven A, hemorrhage, bleeding, blood loss, haemorrhage. Moreover, we reviewed the references of included studies and the included research of related reviews to make the study more complete.

This study followed the statement of the Preferred Reporting Items for Systematic Reviews and MetaAnalyses (PRISMA) [11]. This study analyzed the efficiency and safety of rFVIla in adult non-hemophiliac hemorrhage in randomized controlled trials. The inclusion criteria were as follows: study population: nonhemophiliac patients older than 18 years who require major surgery or hemostatic treatment for cerebral hemorrhage; intervention: rFVIla vs placebo; study design: randomized controlled trials.

We excluded non-RCT trials and RCT study in underage patients on related topics. In addition, studies with fewer than 10 patients in the control or intervention groups were excluded, which we think would affect the accuracy and reliability of the analysis results.

Data Extraction and Assessment of Risk of Bias 
Retrieved studies were selected by two independent investigators according to inclusion and exclusion criteria for the final included trials. Data extraction and literature quality assessment were conducted by two researchers separately for the included studies. The baseline details of the included literatures were arranged in a table, and the extracted data were recorded in an excel datebase according to different outcome events. The primary outcomes included death within 30 days, total thromboembolic events and the milliliter of red cells transfusion with 24 hours. The second outcomes included the numbers of patients with myocardial infarction, arterial events, deep vein thrombosis, red cells transfusion and the days of ICU-stay. The assessment of risk of bias was evaluated by the Cochrane risk of bias tool recommended by the Cochrane Collaboration [12]. Two reviewers independently assessed each domain of included studies and any disagreement was resolved by another investigator.

Statistical Analysis

The risk ratio (RR) with $95 \%$ confidence intervals $(95 \% \mathrm{Cls})$ was calculated for dichotomous data and the mean difference (MD) were estimated by continuous outcomes. The statistical

heterogeneity was evaluated by using Cochran Chi-square test and $\mathrm{I}^{2}$. A fixed-effects model was first used when $I^{2} \varangle 50 \%$ \while $I^{2}>50 \%$ suggested significant heterogeneity, we used a random-effects model to pool the results. Two-tailed P-values $<0.05$ were considered statistical significance. Publication bias was detected using the Funnel plots tests and Egger tests [13]. The effect of publication bias on study results was analysis with trim and fill method. Considering the effect of dose on efficiency, we increased subgroup analysis of red cells infusion volumes. We performed sensitivity analyses of primary outcome events and heterogeneous significant outcomes. All data analysis was conducted by using Review Manager (RevMan; version 5.3) and STATA, version 12.0 (Stata Corporation, College Station, TX).

\section{Results}

Results of search

According to the previous search strategy, 617 studies were obtained from the four database and 2 studies were found by searching the reference lists and reviewed articles. After removing the duplicates, 416 publications remained in total and 401 records were excluded by browsing title and abstract. Among the remaining 15 records, 4 citations were removed according to our inclusion and exclusion criteria. Finally, 11 full-text studies (12 trials, a study consisted of 2 parallel randomized controlled trials) were suitable for this meta-analysis. (Fig. 1). The characteristics, type of hemorrhage and intervention methods of included studies were summarized in Table 1.

Risk of bias within studies

Bias risk of twelve trials was assessed in Fig.2. Two experiments did not provide a detailed method of random processes. Blinding process was at high risk of bias in two studies and unclear risk of bias in one 
study. There is no incomplete data in each study. Five trials did not provide a satisfactory description of reporting bias and nine studies did not indicate the other bias in the article.

Analysis of Primary outcomes

Death

A total of 2,040 patients from nine studies were included in the analysis of 30-day mortality in both rFVIla and control groups. The results showed that $\mathrm{rFVIla}$ did not increase the incidence of death events from meta-analysis [220/1217 vs 139/823, RR=1.00 (0.82-1.21), P for effect $=0.98]$. No heterogeneity was revealed in the result. [P for heterogeneity $\left.=0.83, \mathrm{I}^{2}=0 \%\right]$ (Fig. 3a).

Total thromboembolic events

Total thromboembolic events occurred in 279 of 1786 patients in the experimental group and 143 of 1,083 in the control group [RR=1.13 (0.94-1.36), $P$ for effect=0.20]. No heterogeneity was revealed in the result. $\left[\mathrm{P}\right.$ for heterogeneity $\left.=0.54 \mathrm{I}^{2}=0 \%\right]$ (Fig. 3b).

Volume of red cells transfusion

There were 6 trials that reported the volume of red cells transfusion, with a total of 907 participants. The results showed that there was no significant difference between the two groups [RR $=-168.12(-381.84-$ 45.60), $P$ for effect=0.12]. Heterogeneity was revealed in the result. [P for heterogeneity $₫ 0.01 \otimes I^{2}=76 \%$ ].

Considering the significant heterogeneity of the experimental results, we performed subgroup analysis to

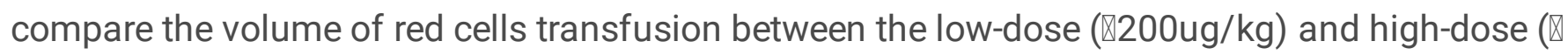
$200 \mathrm{ug} / \mathrm{kg}$ ) groups. In the subgroup of patients with low-dose, rFVIla did not significantly reduce red cells transfusion and there was no statistical difference compared with the control group. [RR $=$ -106.72(-448.33-234.89), $\mathrm{P}$ for effect $=0.54$, $\mathrm{P}$ for heterogeneity $\left.<0.0001, \mathrm{I}^{2}=90 \%\right]$. However, in the subgroup of patients with high-dose, $\mathrm{rFVIla}$ significantly reduced the transfusion of red cells. [RR = $-232.34(-410.31--54.37)$, $P$ for effect $=0.01$, $P$ for heterogeneity $\left.=0.77, \mathrm{I}^{2}=0 \%\right]$. (Fig.3).

Analysis of Second outcomes

arterial events

Compared with the control group, rFVlla significantly increased the incidence of arterial events, and there were no significant heterogeneity. [RR $=1.38(1.08-1.77)$, $\mathrm{P}$ for effect $=0.01, \mathrm{P}$ for heterogeneity $=0.87, \mathrm{I}^{2}=$ 0\%]. (Fig.4a)

Myocardial infarction

In total, 8 studies with 2295 participants reported the incidence of myocardial infarctions after using rFVIla and placebo. The overall analysis showed no increased risk of myocardial infarction [86/1508 vs 
30/787, RR =1.37 (0.92-2.05), $\mathrm{P}$ for effect $=0.13, \mathrm{P}$ for heterogeneity $=0.43, \mathrm{I}=0 \%$. $($ Fig.4b)

Deep vein thrombosis

There are 7 studies that reported the incidence of deep vein thrombosis in this meta-analysis. The RR for DVT with the use of $\mathrm{rFVIla}$ versus placebo was $0.83(95 \% \mathrm{Cl} 0.51-1.33)$ which suggested that $\mathrm{rFVIla}$ would not increase the incidence of DVT. No heterogeneity was revealed in the result. [P for heterogeneity $=0.59, \mathrm{I}^{2}=0 \%$ (Fig. 4c).

Numbers of patients red cell transfusion

The number of red blood cells transfused in the rFVIla group and the control group was 414/497 and $378 / 433$, respectively. [RR $=0.94(0.83-1.08), P$ for effect $=0.39, P$ for heterogeneity $=0.002, I^{2}=77 \%$ ]. (Fig.5a) A random-effects model was chosen in numbers of red cells transfusion because of the high heterogeneity.

ICU-stay

Four trails with a total of 627 participants reported the ICU-stay days. Overall, rFVIla did not significantly reduce length of ICU-stay. $\left[R R=0.40(-1.28-2.07)\right.$, $P$ for effect $=0.64, P$ for heterogeneity $\left.=0.77, \mathrm{I}^{2}=0 \%\right]$ (Fig. 5b).

Publication Bias and Sensitivity Analysis

Funnel plots showed that there was a symmetric distribution of included studied. Egger tests and trim and fill method demonstrated that there was no publication bias in all the studies. Sensitivity analyses have confirmed that all results are robust. All the results were shown in the Supplementary Figures.

\section{Discussion}

This meta-analysis included the latest studies from 2008 to 2019 to compare the safety and efficacy of rFVIla and placebo for patients without hemophilia. Our study contains 12 trials with 2928 (1218 vs 1710) patients and reflects the newest results for the treatment of rFVlla. The study included different types of surgery, such as cardiac surgery; acute intracerebral hemorrhage; postpartum hemorrhage; severe acute pancreatitis; trauma and upper gastrointestinal haemorrhage. The main outcomes were mortality, total thromboembolic events and red cell transfusion requirements. All of included studies were randomized controlled trials. In addition, there were no heterogeneity among studies on most outcomes and sensitivity analysis also suggested the results were not affected by individual research.

In this meta-analysis, we found that there was no statistical difference in the efficacy of rFVIla in reducing blood transfusion and length of ICU- stay compared with the control group. Moreover, we also found that intravenous use of rFVIla did not increase the risk of mortality, total thromboembolic events, myocardial infraction and deep vein thrombosis among patients without hemophilia when compared with placebo 
treatment. However, rFVIla may increase the incidence of arterial events and decrease the volume of blood transfusion in patients receiving high dose $(\$ 200 \mathrm{ug} / \mathrm{kg}) \mathrm{rFVIla}$.

There has been a recent meta-analysis including 28 studies published in 2012 by Simpson et al [25], which compared rFVIla and placebo in patients without hemophilia. However, they only found the arterial events were markedly higher in rFVIla group $(R R=1.45,95 \% \mathrm{Cl}=1.02-2.05, \mathrm{P}=0.04)$, and the red cell transfusion requirements were marked higher in $\mathrm{rFVlla}$ used prophylactically group ( $\mathrm{MD}=-260.78$, $95 \% \mathrm{Cl}=-367.30-154.27, \mathrm{P} \llbracket 0.01)$, while the mortality and total thromboembolic events were similar between rFVIla and placebo groups. Compared with their results, our study included some recent studies, excluded the old publications. The occurrence of different thromboembolic events was analyzed in detail and subgroup analysis of red cell transfusion requirements was performed. We first found that the red cell transfusion requirements have no statistical differences $(M D=-168.12,95 \% \mathrm{Cl}=-381.84-45.60, \mathrm{P}=0.12)$. Moreover, further subgroup analysis showed that the high dose rFVlla significant decrease the red cell transfusion requirements $(\mathrm{MD}=-232.34,95 \% \mathrm{Cl}=-410.31-54.37, \mathrm{P}=0.01)$. In addition, the numbers of patients with red cell transfusion has no statistical difference between rFVIla and placebo group $(R R=0.94,95 \% \mathrm{Cl}=0.83-1.08, \mathrm{P}=0.39)$. However, these analyses have significant heterogeneity which may due to the difference in indications of blood transfusion, drug dose and treatment regimens among different studies.

Similar from the previous studies [26-28], our meta-analysis suggested that rFVIla didn't increase mortality $(R R=1.00,95 \% \mathrm{Cl}=0.82-1.21, \mathrm{P}=0.98)$ and total thromboembolic events $(\mathrm{RR}=1.13,95 \% \mathrm{Cl}=0.94-$ $1.36, \mathrm{P}=0.20$ ) compared with placebo group. Arterial events were significantly higher in rFVIla group $(R R=1.38,95 \% \mathrm{Cl}=1.08-1.77, \mathrm{P}=0.01)$. However, we did not know the severity of arterial events due to no related records in most included studies. So, more comparative studies could try to record specific information about perioperative complications in the future, especially arterial events. In addition, we added a comparison of outcome events such as myocardial infarction, deep vein thrombosis, and length of ICU stay. There was no statistical difference between the two groups. (myocardial infraction: $R R=1.37$, $95 \% \mathrm{Cl}=0.92-2.05, \mathrm{P}=0.13$; deep vein thrombosis: $\mathrm{RR}=0.83,95 \% \mathrm{Cl}=0.52-1.33, \mathrm{P}=0.44$; ICU-stay: $\mathrm{MD}=0.40$, $95 \% \mathrm{Cl}=-1.28-2.07, \mathrm{P}=0.64)$.

In this meta-analysis, we have observed the efficacy and safety of rFVIla. The sub-analysis results showed that high dose rFVIla could reduce red cell transfusion, while low dose rFVIla had no statistical difference compared with the control group. This may be due to the small amount of data or heterogeneity in the included studies, and it is critical that more studies be included to analyze the effect of dose on transfusion volume. In terms of effecacy, rFVIla did not increase mortality or prolong ICU-stay compared with the control group, and there was no statistical difference between the two groups. In terms of safety, rFVIla did not increase the incidence of total thromboembolic events, deep vein thrombosis and myocardial infarction. Unfortunately, however, rFVIla significantly increased the incidence of arterial events, which should be noted. 
We acknowledge some potential limitations in this study that should be considered. Firstly, heterogeneity due to clinical and methodological diversity was inevitable which may affect the reliability of the analysis results especially in meta-analyses of transfusion. Secondly, we used different measurement units for conversion, which may affect the reliability of the experimental results. Despite the above limitations, the current study is still the most comprehensive analysis on the efficacy and safety of rFVIla in patients without hemophilia with sufficient sample size.

\section{Conclusion}

The current study systematically reviewed the existing evidence on the efficacy and safety profile of rFVIla in patients without hemophilia. The results show that high dose rFVIla would significantly reduce transfusion of red cell. rFVIla did not increase mortality, ICU-stay, total thromboembolic events, deep vein thrombosis and myocardial infarction. However, rFVIla increases arterial events, which deserves further study. Overall, intravenous administration of rFVIla in major surgery is effective and safe in reducing blood transfusion according to the existing evidence and further studies are needed to identify the optimal dose and regime for intravenous use of rFVIla to achieve the best benefit with lowest risk.

\section{Declarations}

Ethics approval and consent to participate

Not applicable.

Consent for publication

Not applicable.

Availability of data and materials

All data generated or analysed during this study are included in this published article and its supplementary information files.

Competing interests

The authors declare that they have no competing interests.

Funding

This work was supported by the medical and health science and technology project of

Zhejiang in writing and reviewing of manuscript. (Grant No. 2019RC044).

Author's contributions 
$Y Z$, JL and HYZ were involved in the study design, data review, data analysis, writing paper, review and approval of final manuscript. YTW, YFZ and HYZ were involved in data review, data analysis, review and approval of final manuscript. All authors read and approved the final manuscript.

Acknowledgements

Not applicable

\section{Abbreviations}

rFVlla: Recombinant human factor Vlla

RCT: randomized controlled trials

RR: risk ratio

Cl: confidence intervals

MD: mean difference

\section{References}

1. Mannucci PM, Levi M. Prevention and treatment of major blood loss. N Engl J Med. 2007;356:23012311.

2. Karkouti K, Wijeysundera DN, Yau TM, et al. The independent association of massive blood loss with mortality in cardiac surgery.Transfusion. 2004;44:1453-1462.

3. Janet B, Simon J. Stanworth, et al. Evidence for the Use of Recombinant Factor VIla in the Prevention and Treatment of Bleeding in Patients Without Hemophilia. Transfusion Medicine Reviews, Vol 22, No 3 (July), 2008: pp 177-187

4. Monroe DM, Hoffman M, Oliver JA, et al: Platelet activity of high dose factor Vlla is independent of tissue factor. Br J Haematol 99:542-547, 1997

5. Levi M, Levy JH, Andersen HF, Truloff D (2010) Safety of recombinant activated factor VII in randomized clinical trials. N Engl J Med 363: 1791-1800.

6. Kenet G, Walden R, Eldad A, et al: Treatment of traumatic bleeding with recombinant factor VIla. Lancet 354:1879, 1999

7. Aaron C. Logan and Lawrence T. Goodnough. Recombinant Factor VIla: An Assessment of Evidence Regarding Its Efficacy and Safety in the Off-Label Setting. CONSULTATIVE HEMATOLOGY: HEMOSTASIS AND THROMBOSIS $2010: 153-159$

8. Habib AM. Comparison of low- and high-dose recombinant activated factor VII for postcardiac surgical bleeding. Indian J Crit Care Med 2016;20:497-503. 
9. White MC, Pryn SJ, Monk CR. Thrombogenic side-effects of recombinant factor Vlla after use in coronary artery bypass surgery. Anaesth Intensive Care 2006;34:664-7

10. Hsia CC, Zurawska JH, Tong MZY, Eckert K, McAlister VC, Chin-Yee IH. Recombinant activated factor $\mathrm{VII}$ in the treatment of non-haemophilia patients: physician under-reporting of thromboembolic adverse events. Transfus Med. 2009;19:43-49.

11. Moher D, Liberati A, Tetzlaff J, Altman DG, Group P. Preferred reporting items for systematic reviews and meta-analyses: the PRISMA statement. J Clin Epidemiol. 2009;62:1006-12.

12. Higgins JP, Altman DG, Gotzsche PC, et al. The Cochrane Collaboration's tool for assessing risk of bias in randomised trials. BMJ. 2011;343:d5928

13. Sterne JA, Sutton AJ, loannidis JP, et al. Recommendations for examining and interpreting funnel plot asymmetry in meta-analyses of randomised controlled trials. BMJ. 2011;343:d4002.

14. David JG, Richard IA, Andrew MD, et al. Effect of Recombinant Activated Coagulation Factor VII on Hemorrhage Expansion Among Patients With Spot Sign-Positive Acute Intracerebral Hemorrhage The SPOTLIGHT and STOP-IT Randomized Clinical Trials. JAMA Neurology. August 19, 2019

15. Narges P, Mahnoosh F, Ali D. The Effect of Intravenous Administration of Active Recombinant Factor VII on Postoperative Bleeding in Cardiac Valve Reoperations; A Randomized Clinical Trial. Anesth Pain Med. 2015 February; 5(1): e22846.

16. Lavigne-Lissalde G, Aya AG, Mercier FJ, et al. Recombinant human FVIla for reducing the need of invasive second-line therapies in severe refractory postpartum hemorrhage: a multicenter, randomized, open controlled trial. J Thromb Haemost 2015;13: 520-9

17. Jun Lu, Lian-ming Liao, Yan-xia Geng, et al. A double-blind, randomized, controlled study to explore the efficacy of $\mathrm{rFVIla}$ on intraoperative blood loss and mortality in patients with severe acute pancreatitis. Thrombosis Research 133 (2014) 574-578

18. Mohamed Essam Abdel-Meguid. Prophylactic administration of recombinant activated factor VII in coronary revascularization surgery. Saudi Journal of Anaesthesia.Vol. 7, Issue 3, July-September 2013

19. R. IMBERTI, L. PIETROBONO, C. KLERSY, et al. Intraoperative intravenous administration of rFVIla and hematoma volume after early surgery for spontaneous intracerebral hemorrhage: a randomized prospective phase II study. MINERVA ANESTESIOLOGICA 2012 Vol. 78 - No. 2 168-175

20. Carl J. Hauser, Kenneth Boffard, Richard Dutton, et al. Results of the CONTROL Trial: Efficacy and Safety of Recombinant Activated Factor VII in the Management of Refractory Traumatic Hemorrhage. J Trauma. 2010;69: 489-500

21. Michael ND, Brett ES, Stephan AM, et al. Thromboembolic Events With Recombinant Activated Factor VII in Spontaneous Intracerebral Hemorrhage Results From the Factor Seven for Acute Hemorrhagic Stroke (FAST) Trial. Stroke. 2010;41:48-53

22. Ravi Gill, BM, Mike H, Alain V, et al. Safety and Efficacy of Recombinant Activated Factor VII A Randomized Placebo-Controlled Trial in the Setting of Bleeding After Cardiac Surgery. Circulation. 2009;120:21-27.) 
23. Stephan AM, Nikolai CB, Kamilla B, et al. Efficacy and Safety of Recombinant Activated

24. Factor VII for Acute Intracerebral Hemorrhage. N Engl J Med 2008;358:2127-37

25. Jaime Bosch, Dominique Thabut, Agustín Albillos, et al. Recombinant Factor VIla for Variceal Bleeding in Patients with Advanced Cirrhosis: a Randomized, Controlled Trial. HEPATOLOGY 2008;47:1604-1614.

26. Simpson E, Lin Y, Stanworth S, Birchall J, Doree C, Hyde C. Recombinant factor VIla for the prevention and treatment of bleeding in patients without haemophilia. Cochrane Database of Systematic Reviews 2012, Issue 3. Art. No.: CD005011. DOI: 10.1002/14651858.CD005011.pub4.

27. Chavez-Tapia NC, Alfaro-Lara R, Tellez-Avila F, Barrientos-Gutie'rrez T, Gonza'lez-Chon O, et al. (2011) Prophylactic Activated Recombinant Factor VII in Liver Resection and Liver Transplantation: Systematic Review and Meta-Analysis. PLoS ONE 6(7): e22581. doi:10.1371/journal.pone.0022581

28. Alberto Z, Anna M, Giuseppe BZ, et al. Recombinant Activated Factor VII in Cardiac Surgery: A Metaanalysis. Journal of Cardiothoracic and Vascular Anesthesia, Vol 23, No 1 (February), 2009: pp 34-40

29. Martin P, Giovanni L, Giuseppe BZ, et al. Recombinant Activated Factor VII Increases Stroke in Cardiac Surgery: A Meta-analysis. Journal of Cardiothoracic and Vascular Anesthesia, Vol 25, No 5 (October), 2011: pp 804-810

\section{Table}




\begin{tabular}{|c|c|c|c|c|}
\hline Country & $\begin{array}{l}\text { No. } \\
\mathrm{C} / \mathrm{T}\end{array}$ & $\begin{array}{l}\text { Sex } \\
F / M\end{array}$ & $\begin{array}{c}\text { Type of } \\
\text { hemorrhage }\end{array}$ & Intervention \\
\hline Canada & $37 / 32$ & $34 / 35$ & $\begin{array}{l}\text { Acute } \\
\text { Intracerebral } \\
\text { Hemorrhage }\end{array}$ & $\begin{array}{l}\text { Group1. } 1 \text { dose of } 80 \mathrm{ug} / \mathrm{kg} \text { rFVIIa iv } \\
\text { within } 6 \text { hours from stroke onset in the } \\
\text { SPOTLIGHT trial or } 6.5 \text { hours in the } \\
\text { STOP-IT trial. } \\
\text { Group2. Placebo, saline, at same time }\end{array}$ \\
\hline
\end{tabular}

Iran $\quad 18 / 18 \quad 12 / 24 \quad$ Cardiac Valve Group1. 1 dose of $40 \mu \mathrm{g} / \mathrm{kg}$ rFVIIa iv Reoperations after reversal of heparin.

Group2. Placebo, saline, at same time

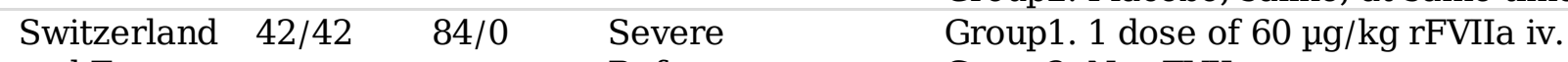
and France $\quad$ Refractory Group2. No rFVIIa

Postpartum Hemorrhage

7] China 33/31 20/44 $\begin{array}{ll}\begin{array}{l}\text { Severe Acute } \\ \text { Pancreatitis }\end{array} & \begin{array}{l}\text { Group1. } 1 \text { dose of } 40 \mu \mathrm{g} / \mathrm{kg} \mathrm{rFVIIa} \text { was } \\ \text { administered intravenously } 10 \text { minutes } \\ \text { before surgery. } \\ \text { Group2. Placebo, saline, at same time }\end{array}\end{array}$

$\begin{array}{lllll}\text { uid } \begin{array}{l}\text { Saudi } \\ \text { Arabia }\end{array} & 15 / 15 & \text { NA } & \begin{array}{l}\text { Coronary } \\ \text { Revascularization } \\ \text { Surgery under } \\ \text { CPB }\end{array} & \begin{array}{l}\text { Group1. a dose of 90 ug/Kg of rFVIIa } \\ \text { was administered following weaning } \\ \text { off CPB. } \\ \text { Group2. Placebo, saline, at same time }\end{array} \\ & & \end{array}$

$\begin{array}{ccll}\text { Italy } 8 / 13 \quad 5 / 16 & \begin{array}{l}\text { Spontaneous } \\ \text { Intracerebral } \\ \text { Hemorrhage }\end{array} & \begin{array}{l}\text { Group1. } 100 \mathrm{mcg} / \mathrm{kg} \text { of rFVIIa by } \\ \text { intravenous infusion in 5-10 minutes } \\ \text { immediately after evacuation of the } \\ \text { hematoma at the beginning of the } \\ \text { closure of the dura. } \\ \text { Group2. Placebo, saline, at same time }\end{array} \\ & \end{array}$

$26 \quad 247 / 221$ NA $\quad$ Blunt Trauma

countries

$\begin{array}{llll}26 & 40 / 46 \quad \text { NA } & \begin{array}{l}\text { Penetrating } \\ \text { Trauma }\end{array}\end{array}$

Group 1. 3 doses of iv rFVIIa. 200 $\mu \mathrm{g} / \mathrm{kg}$ first dose, after 8 units of RBC transfused; 100 $\mu \mathrm{g} / \mathrm{kg} 1$ hour after dose 1; $100 \mu \mathrm{\mu g} / \mathrm{kg} 3$ hours after dose 1 . Total dose 400 $\mu \mathrm{g} / \mathrm{kg}$.

Group 2. Placebo given at each of the 3 time points.

Group 1. 3 doses of iv rFVIIa. 200 $\mu \mathrm{g} / \mathrm{kg}$ first dose, after 8 units of RBC transfused; 100

$\mu \mathrm{g} / \mathrm{kg} 1$ hour after dose 1; $100 \mu \mathrm{\mu g} / \mathrm{kg} 3$ hours after dose 1 . Total dose 400 $\mu \mathrm{g} / \mathrm{kg}$.

Group 2. Placebo given at each of the 3 time points. 


\begin{tabular}{|c|c|c|c|c|c|}
\hline$)$ & Country & $\begin{array}{l}\text { No. } \\
\text { C/T }\end{array}$ & $\begin{array}{l}\text { Sex } \\
\mathrm{F} / \mathrm{M}\end{array}$ & $\begin{array}{c}\text { Type of } \\
\text { hemorrhage }\end{array}$ & Intervention \\
\hline & $\begin{array}{l}22 \\
\text { countries }\end{array}$ & $558 / 263$ & $322 / 519$ & $\begin{array}{l}\text { Spontaneous } \\
\text { Intracerebral } \\
\text { Hemorrhage }\end{array}$ & $\begin{array}{l}\text { Group } 1.1 \text { dose of } 20 \mu \mathrm{g} / \mathrm{kg} \text { of rFVIIa } \\
\text { iv within } 1 \text { hour of CT scan. } \\
\text { Group 2. } 1 \text { dose of } 80 \mu \mathrm{g} / \mathrm{kg} \text { at same } \\
\text { time. } \\
\text { Group 3. Placebo at same time. }\end{array}$ \\
\hline \multirow[t]{3}{*}{ :2] } & $\begin{array}{l}13 \\
\text { countries }\end{array}$ & $68 / 104$ & $44 / 128$ & $\begin{array}{l}\text { Cardiac Surgery } \\
\text { Requiring CPB }\end{array}$ & $\begin{array}{l}\text { Group } 1=\text { rFVIIa } 40 \mu \mathrm{g} / \mathrm{kg} \\
\text { Group } 2=\text { rFVIIa } 80 \mu \mathrm{g} / \mathrm{kg} \\
\text { Group } 3=\text { Placebo }\end{array}$ \\
\hline & $\begin{array}{l}22 \\
\text { countries }\end{array}$ & $558 / 263$ & $322 / 519$ & $\begin{array}{l}\text { Spontaneous } \\
\text { Intracerebral } \\
\text { Hemorrhage }\end{array}$ & $\begin{array}{l}\text { Group } 1.1 \text { dose of } 20 \mu \mathrm{g} / \mathrm{kg} \text { of rFVIIa } \\
\text { iv within } 1 \text { hour of CT scan. } \\
\text { Group 2. } 1 \text { dose of } 80 \mu \mathrm{g} / \mathrm{kg} \text { at same } \\
\text { time. } \\
\text { Group 3. Placebo at same time. }\end{array}$ \\
\hline & $\begin{array}{l}12 \\
\text { countries }\end{array}$ & $86 / 170$ & $69 / 187$ & $\begin{array}{l}\text { Upper } \\
\text { Gastrointestinal } \\
\text { Haemorrhage }\end{array}$ & $\begin{array}{l}\text { Group } 1 \text {. First dose } 200 \mu \mathrm{g} / \mathrm{kg} \mathrm{rFVIIa} \mathrm{iv} \\
\text { followed by doses of } 100 \mu \mathrm{gg} / \mathrm{kg} \text { at } 2,8 \text {, } \\
14 \text { and } \\
20 \text { hours after initial dose. Total dose } \\
600 \mu \mathrm{gg} \\
\text { Group } 2 \text {. First dose } 200 \mu \mathrm{g} / \mathrm{kg} \mathrm{rFVIIa} \mathrm{iv} \\
\text { followed by second dose of } 100 \mu \mathrm{g} / \mathrm{kg} \\
\text { at } 2 \\
\text { hours and placebo at } 8,14 \text { and } 20 \\
\text { hours after initial dose. Total dose } 300 \\
\mu \mathrm{g} / \mathrm{kg} \\
\text { Group 3. Placebo at same times. }\end{array}$ \\
\hline
\end{tabular}

\section{Figures}




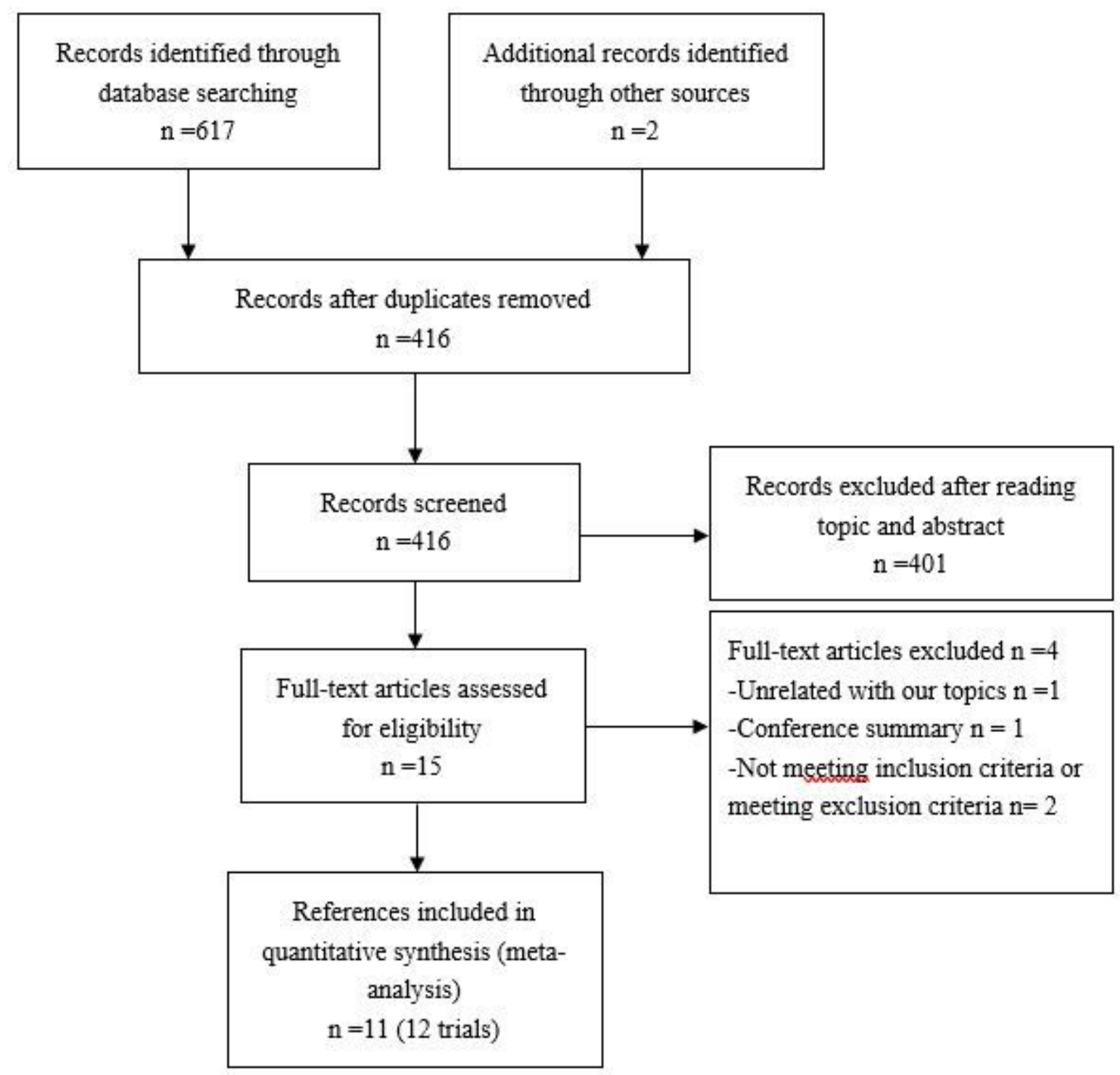

Figure 1 
A

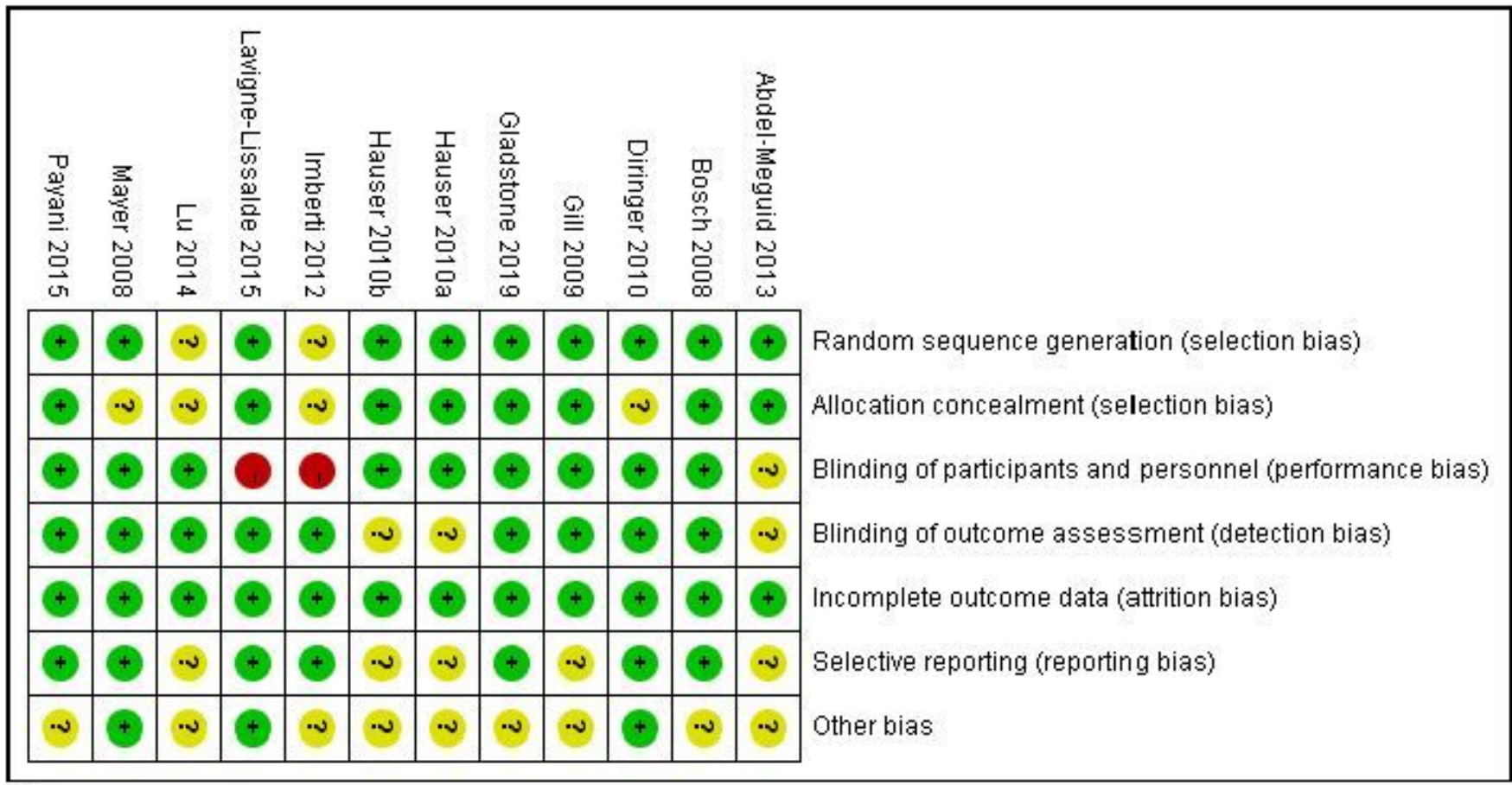

$\mathrm{B}$

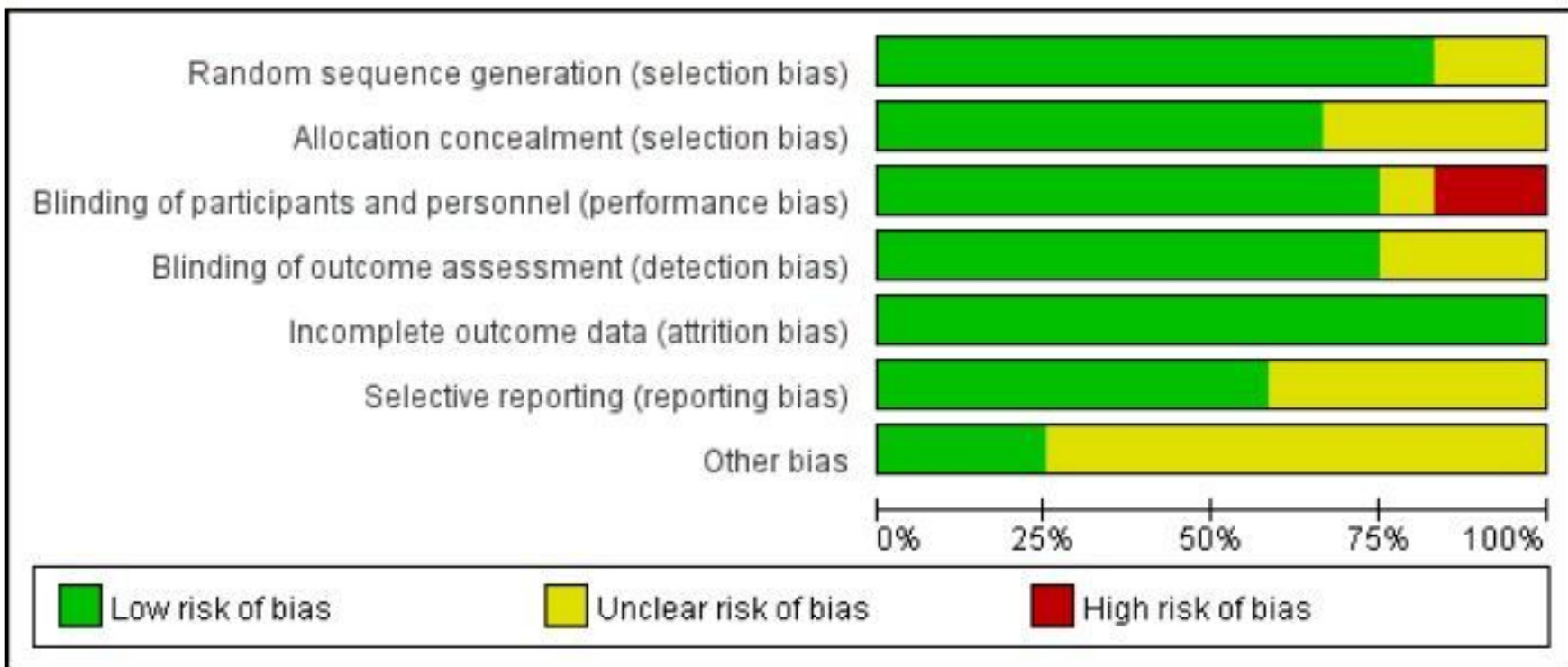

Fig 2 A. risk-of-bias summary; B. risk-of-bias graph for all the included randomized-controlled trials

\section{Figure 2}




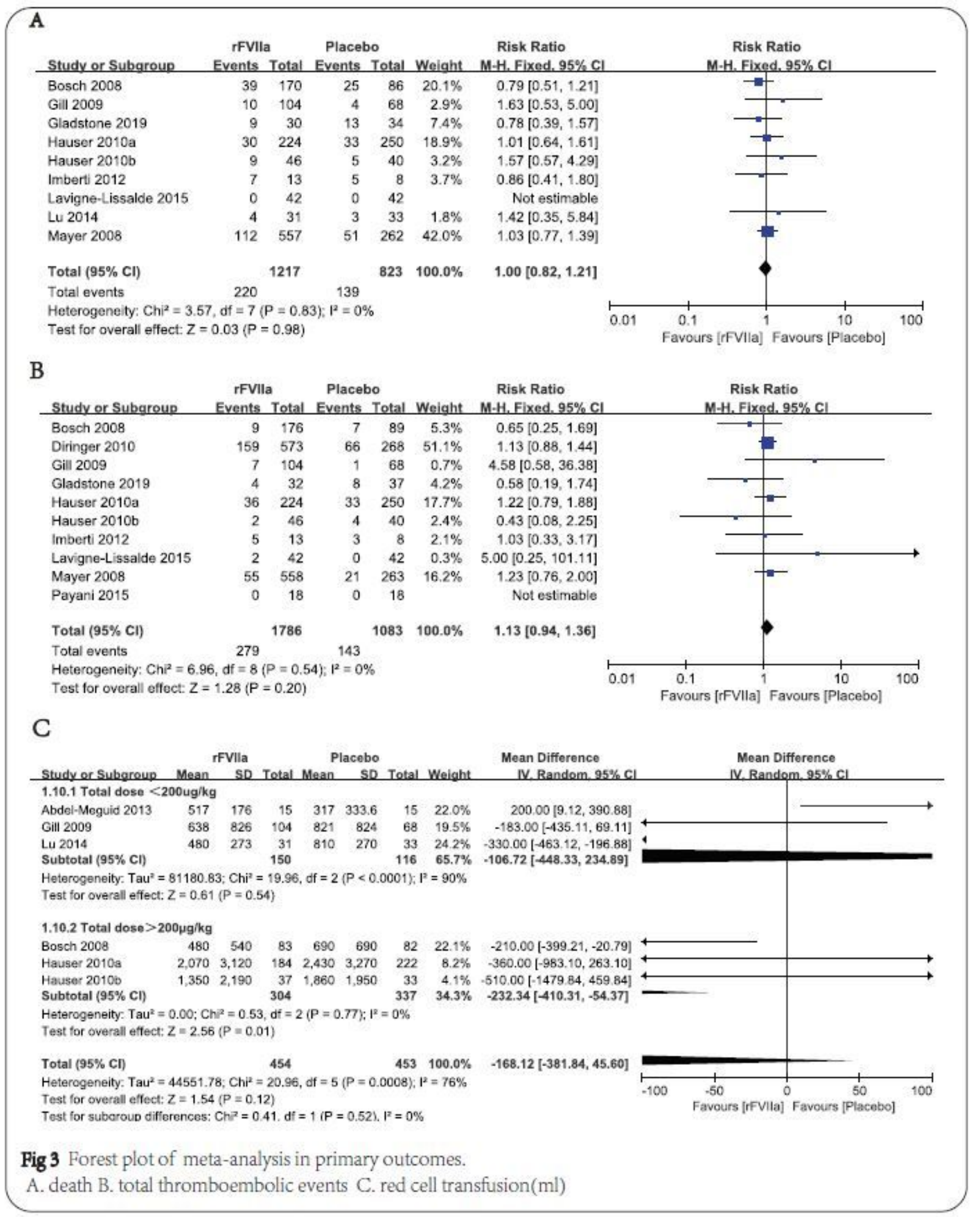

\section{Figure 3}


A

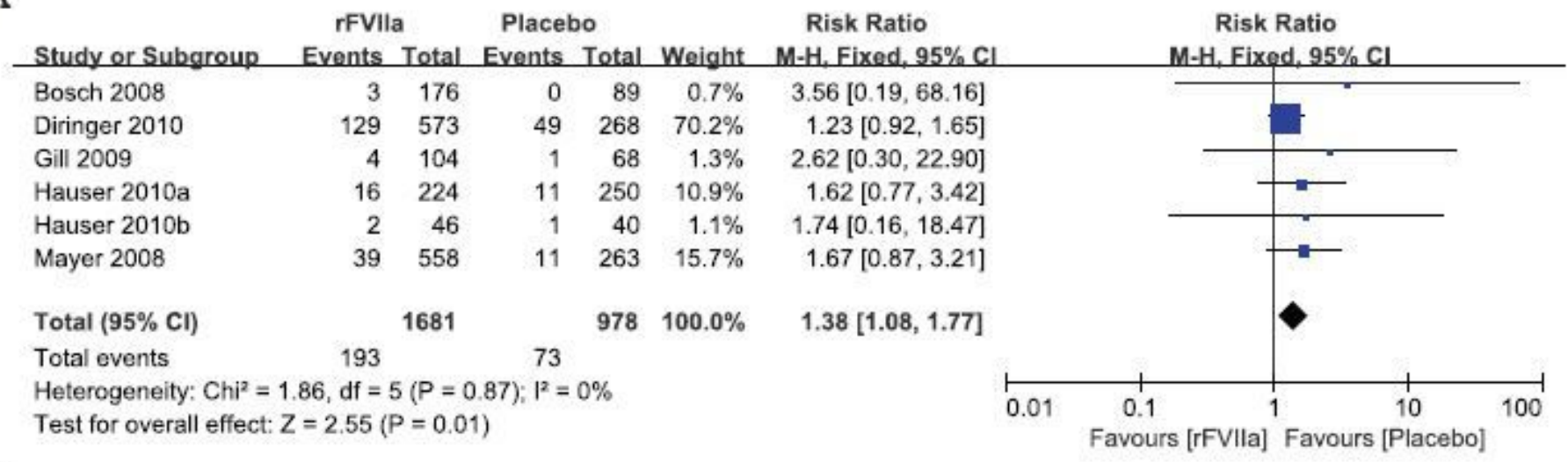

B

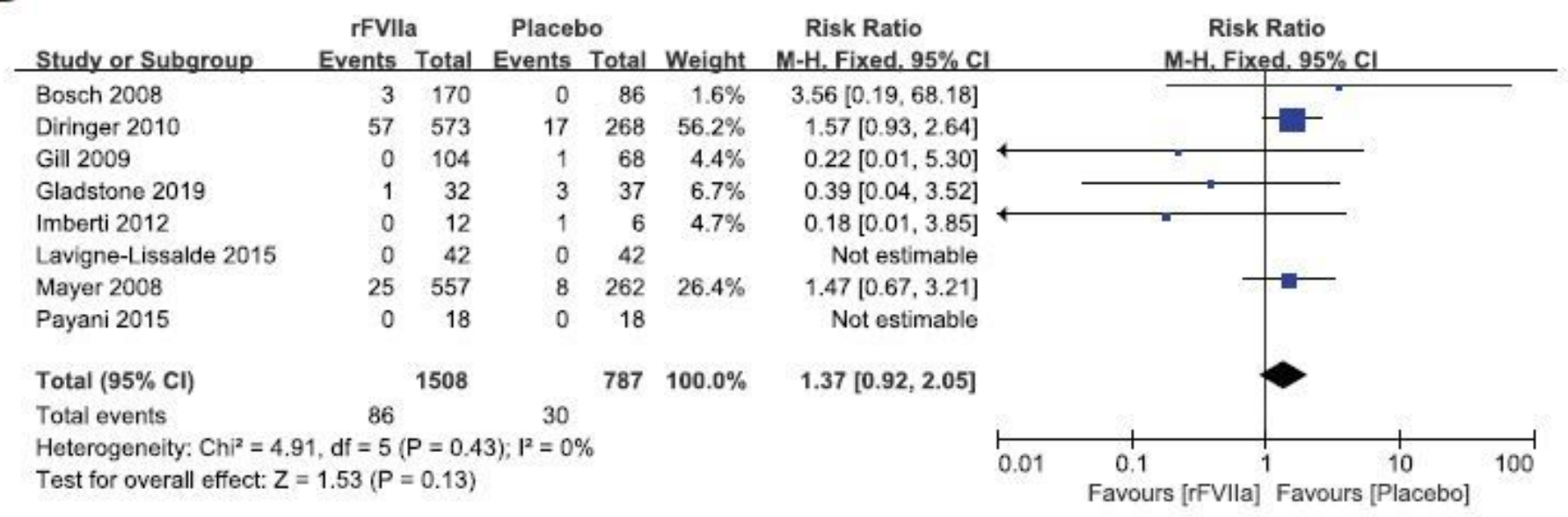

C

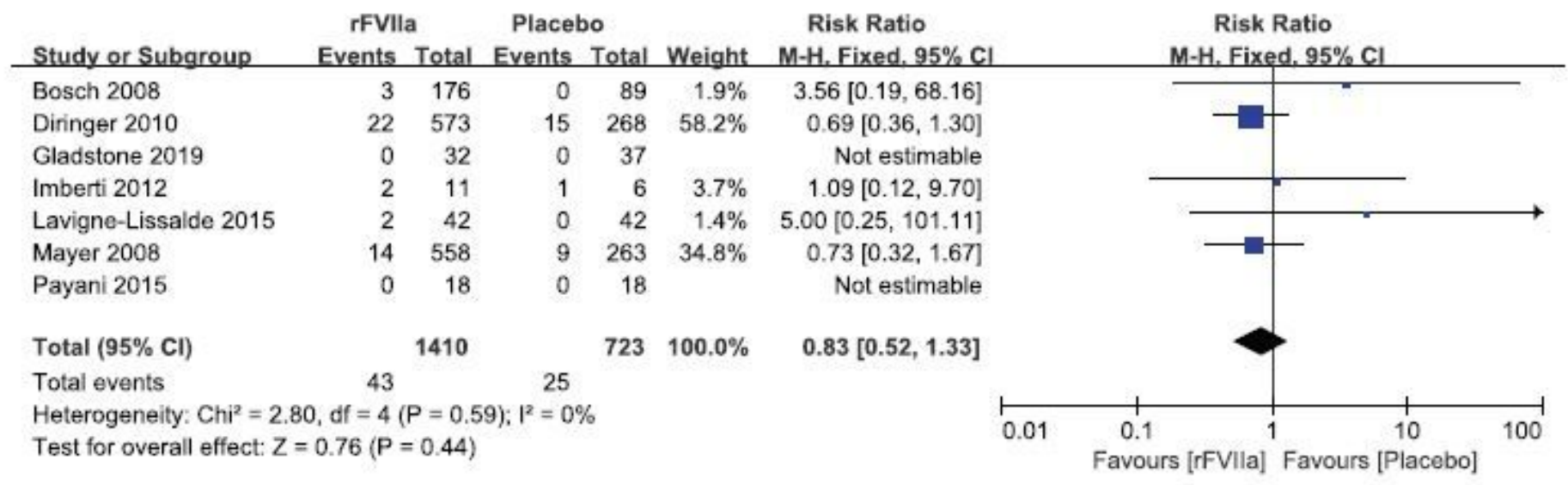

Fig 4 Forest plot of meta-analysis in second outcomes.

A. arterial events B. myocardial infraction C. deep vein thrombosis

\section{Figure 4}


A

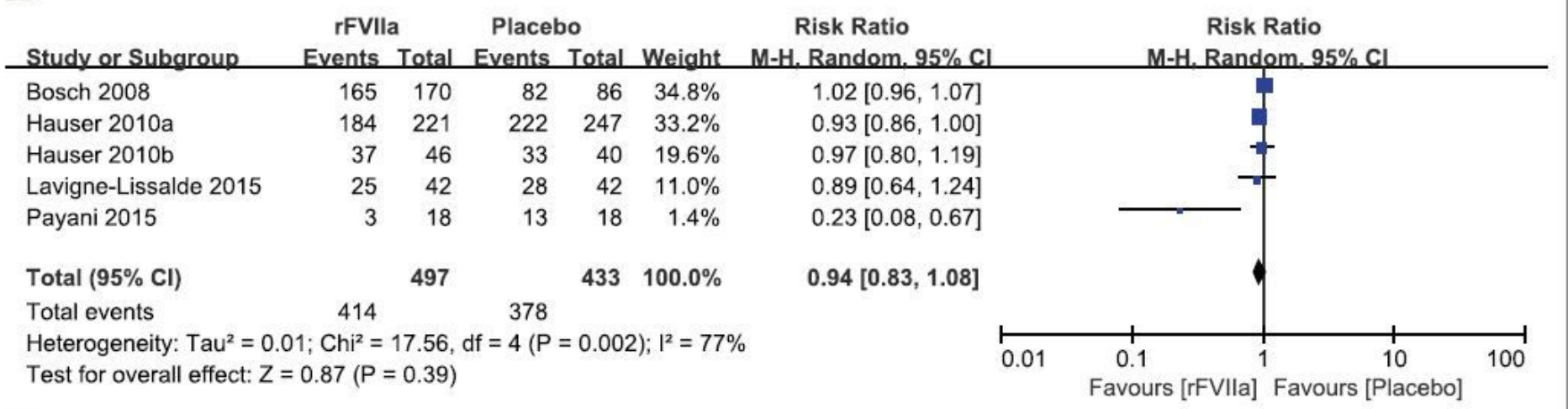

B

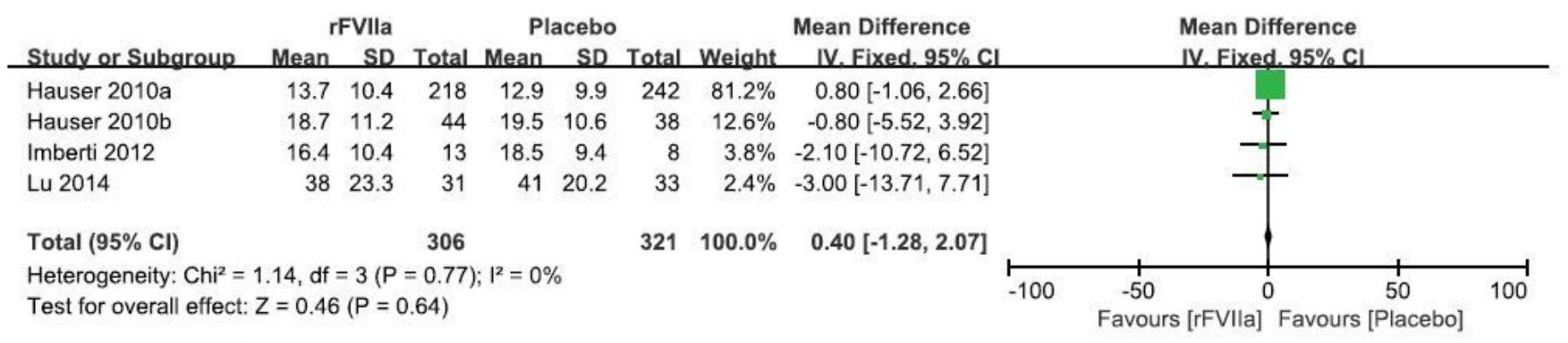

Fig 5 Forest plot of meta-analysis in second outcomes.

A. numbers of patients red cell transfusion B. ICU-stay (d)

\section{Figure 5}

\section{Supplementary Files}

This is a list of supplementary files associated with this preprint. Click to download.

- Figs2.pdf

- FigS1.pdf

- FigS3.pdf

- PRISMA2009checklist.doc 